\title{
Research on a New Training Mode for Applied Internationalized Talents under "OBOR"
}

\author{
Dehong Zhao ${ }^{1^{*}}$, Yuhou $\mathrm{Wu}^{1}$ and Linan $\mathrm{Hu}^{2}$ \\ ${ }^{1}$ School of mechanical engineering, Shenyang Jianzhu University, Shenyang 100168, China; \\ ${ }^{2}$ Recruitment and Employment Office, Shenyang Jianzhu University, Shenyang 100168, China; \\ ajtjxzdh@sjzu.edu.cn, ${ }^{b}$ wuyh@sjzu.edu.cn, ${ }^{c} 31335353 @ q q . c o m$
}

Keywords: The Belt and Road; International Education; International Student Education; Training Mode; Application-oriented International Talents

\begin{abstract}
Under the background of "OBOR" area development strategy, more and more internationalized application-oriented professionals is required in multinational corporations and most countries along the route. As a new way of personnel training, the personnel training mode of mechanical engineering students in Shenyang Jianzhu University is exampled in this article, in which the international education and education for international students are mixed together. By forming international engineering class, completing teaching management mode and curriculum system, carrying interactive learning, reforming the examination and appraisal way, domestic students and foreign students are organized together, learning knowledge, discussing each other's language, cultural, social, religious, and so on.
\end{abstract}

\section{Introduction}

Under the background of economic globalization, persons having sustainable development of the internationalization and international teamwork ability are required by a growing number of companies $^{[1,2]}$. In recent years, A large number of international education research project on a small number of elite students are carried out, such as cross-school communication joint training undergraduates $^{[3]}$, international access the academic team ${ }^{[4]}$, international exchanges and cooperation projects $^{[5]}$ and so on, in order to develop research students. Existing research mainly focused on the selection of teaching material, teaching language, training plan and so on, such as CHONGQING university school of mechanical engineering with the introduction of the talent cultivation system of the national university of Singapore ${ }^{[6]}$. But, international talents need not only have good language communication ability and solid professional foundation, more need to have the broad international vision; strong ability of intercultural communication; as well as higher political and ideological quality and healthy psychological quality

In the same period, as China's international influence gradually increase, more and more foreign students to studying Chinese, foreign student education has become an important part of the internationalization of education. Students to the fundamental purpose is to learn Chinese, learn professional knowledge not only, more important is to understand Chinese culture, share in China's development dividends. The purpose of the internationalization of education is to make the domestic students with international vision, have the ability to engaged in professional and technical services in relevant countries. As to the internationalization of education for international students and domestic students education management as a whole, the fusion penetration, supplement each other, not only can save teaching resources, it can raise the level of internationalization of undergraduate teaching and students and teaching, enable students to better understand the foreign culture, to adapt to the international communication.

\section{Characteristics of demands for international talents under “OBOR”}

The "OBOR" strategy is a great strategic deployment to achieve the "Two Centenary" goals, which is the creation of benefiting people of all nationalities along the road ${ }^{[7]}$. The key to the implementation 
of the Belt and Road strategy is talent. However, the economic corridor across the Eurasia, involve 65 countries and regions, there is a large gap between these countries such as the social culture, economic development level and political system, it bring the higher, more complex requirement on the training of international talents which is mainly manifested in the following respects ${ }^{[8]}$.

(1) Most countries along the road of "OBOR" are developing countries and the industry foundation is weak, there are large demand for application engineering and technical personnel in these countries. There are 65 countries and regions along the line of "OBOR", a total population of these areas is 4.4 billion which taking up 63 percent of the world. But the economic aggregate of these countries is only 21 trillion dollars which taking up 29 percent of the world ${ }^{[9]}$. Although the resource-based country such as Saudi Arabia is rich, the industrial foundation is still weak. Therefore, the biggest industry promoted by "OBOR" is the infrastructure construction industry and the biggest talent gap is the application engineering and technical personnel.

(2) The knowledge hierarchy of international talents needs to be more specific on account of the difference of cultural background and technical standard. There are complex historical and cultural backgrounds in the countries along the road of "OBOR", most of these countries have the colonization history and there is a certain unity in the fields of language culture and technological development, but the difference takes a leading. For instance, in the engineering drawing field, the West Asia and central and Eastern Europe countries as Iran mainly using the first angle method, while the former British colonies countries as India mainly using the third angle method ${ }^{[10]}$.

(3)There are higher requirements of comprehensive quality of international talents due to the difference of religion and social conventions. Over 66 percent people are religious in the countries along the "OBOR" line. Part of the areas has an extremely complicated relation religious policy, Church-State Relations and communicative relationship ${ }^{[11]}$. So the international talents need to have a strong understanding of religious issue relate to "OBOR", mobilize positive factor of related religions to avoid the negative effects which generates a smooth, peaceful and effective development of the “OBOR” construction.

\section{Composition of the international engineering technology class}

Shenyang Jianzhu University is a institute for machinery, construction and civil engineering as the main characteristics, the Mechanical engineering disciplines is the first-class discipline of Liaoning Province. The Mechanical Design Manufacturing and Automation specialty is the advantageous specialty, international pilot specialty of the curriculum system of undergraduate course of common colleges and universities of Liaoning Province, this specialty cultivating high-level applied engineering talents for engineering construction industry. There are nearly 40 percent University Graduates entered into the large state-owned construction group such as China State Construction Engineering Corporation and China Railway Construction Corporation Limited, part of them entered into the large engineering machinery manufacturing enterprises such as Sany Heavy Industry and ZOOMLION, there are 60 percent among these graduates turned into the overseas department of their company and engaged in international engineering construction and technical services. There are 20 abroad student in this specialty were cultivated to the countries along the "OBOR" line.

The International Mechanical Engineering Technology courses of SHENYANG JIANZHU UNIVERSITY is a featured orientation of education, in allusion to the International talent training demands of "OBOR", combine the international education of undergraduate curriculum system and foreign students education, these courses cultivate the application engineering and technical personnel that master the basic knowledge of mechanical discipline, with the international engineering service consciousness and ability, the application engineering and technical personnel can also engage in mechanical engineering and equipment design, service , maintenance, selling and operating management. The students of the class consist of domestic undergraduate students and international students which is configured by 1:1 or 35 persons. Domestic undergraduate students can declare the International engineering technology class during the first semester of second year. The 
professional teaching committee would choose some students and international students preferential according to the filing condition, foreign language level and comprehensive quality. The International Mechanical Engineering Technology courses is ont limited to mechanical engineering students, but also the majors related to mechanical engineering.

\section{Innovation of teaching management model}

Student management: Single class management mode was used in the international engineering technology class, which has the independent educational occupancy, centralized management was used on students. The class allocated the professional academic advisor and student management service supervisor. The basic length of schooling is four years, the student status as a retained for a maximum period of eight years. The credit-based system was used in the student status management, and the graduation total credit that not less than 190 credits. The student can achieve their degrees through course assessment and final project defense.

Teaching management: the professional teaching steering committee was built in college, the committee take charge of making this professional student talent training plan which including the talent training scheme of International engineering and technical talents, in this scheme, greatly reduction on the compulsory course and appropriate increase on the elective courses, course selection and the proportion of practice teaching area. The proportion of compulsory credits and elective credits no more than 1:1. All the courses of the international engineering technology class were calculated the coefficient according to bilingual courses and examination reform course, the teaching load is calculated by undergraduate course and foreign student course respectively.

Teaching operation: the international engineering and technical instruction was built in collage, in charge of teaching operation and management. The principle of short term matching class was used in the international engineering technology class, the biggest course period is 32.All courses were set up within former 8 weeks and later 8 weeks to guarantee the cohesion between the courses. For example, the 'mechanical principle', has 32 periods 'Mechanical principles basis' in the international engineering technology class in the former 8 weeks, there is 2 credits for students who have attended courses examination according to the teaching plan. On the other hand, students can continued in the 'mechanical principle' (64 periods) of the major after finishing former 8 weeks international class study, and then obtain 4 credits through the corresponding course examination.

\section{Innovation of course system and teaching mode}

As shown in Figure 1,it is the logic diagram about international project of cultivating engineering and technical direction. The feature mainly includes the following several aspects:

(1)The direction of machinery international engineering technology in Shenyang Jianzhu University featuring Construction engineering machine includes the characteristics of professional courses in four directions, which are mechanical and electrical engineering, mechanical design, mechanical manufacturing and automation, industrialization of modern architecture.

(2)In the first school year, international students were mainly composed of language learning, and ordinary undergraduate students will select courses base on requirement of profession. Second-year,we will set up socialism with Chinese characteristics and international politics, international trade etc. These courses adopt interactive teaching mode, the purpose is to strengthen the student to "area all the way along the" national geographic, cultural, social, religious, environmental education.

(3)Add the curriculum system of international standards, which contains two parts of the national standards, international standards, this course was divided into two semesters. We want our students to understand the technical standards in different countries, to adapt to the "area" project technical requirements by the teaching content.

(4)The professional way of teaching is small-classroom and few class hour. Course maximum period is 32 hours, and adopt flexible academic year credit system. The teaching plan and professional 
direction of teaching plan to run at the same time. After complete the international class, students can enter the large professional continue to study at a deeper level.

(5)The direction of the course is encouraging the interactive teaching mode, which all course included in the examination reform course sequence, the final question paper grades than less than $40 \%$, the routine assessments accounted for a larger proportion in the results. Meanwhile, we should actively promote courses related to application of modern network technology, Internet technology, including mechanical principles, mechanical design, such as "mechanical manufacturing technology foundation" course has achieved network interactive teaching.

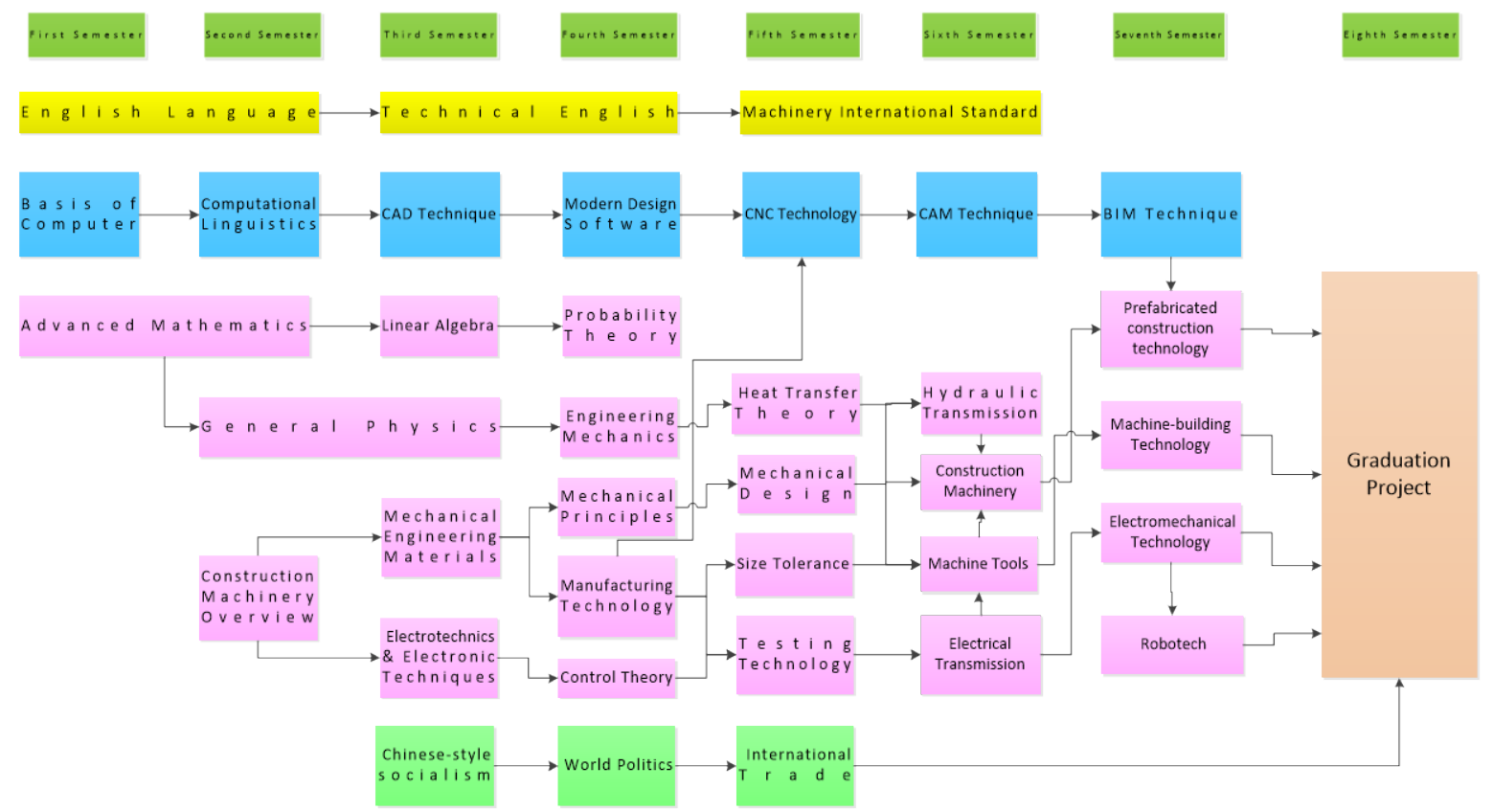

Fig. 1 Logic Chart of Training Program for International Engineering Students

(6)The group teaching model was used in the teaching practice period. The integrated practice teaching system is established with the original specialty, including a variety of functions such as fundamental experiment teaching, engineering quality training, public analysis test and innovative training, also consist of the four-party integration as professional knowledge, basic skills, professional knowledge application and comprehensive ability training.

(7) In the direction of international engineering, special reward policy was set up, used to encourage students from different countries to form a team, innovative start-ups and subject competitions.

\section{Summary}

Under the background of "OBOR" area development strategy,applied internationalized talents is one of the biggest talent gap. Through forming the international engineering class, the internationalization of education and the education for international students are combined together in mechanical engineering talents cultivation of Shenyang Jianzhu University, in which the teaching resources by saving, efficiency and level be improved. The graduation rates is ensured by reforming of the teaching management mode and curriculum system, using academic year credit training system, increasing the proportion of elective courses, configurating less school curriculum and setting the academic advisor.

\section{References}

[1]. Jiang Bin, Hu Han. An analysis of talent cultivation of high iron in "The Belt and Road" strategy system [J]. Human resources development, 2015, 18, pp.49-50. 
[2]. Wenjun, Jiang Xianling. System thinking innovation of University international talents training path of The Belt and Road [J]. International business (Journal of University of International Business and Economics), 2015, 05, pp.153-160.

[3]. Deng Chun, Zhang Xianqi, Li Chan. "The Belt and Road" strategy of internationalization of talents in higher education on the cultivation of the pattern and Path -- a case study of Hainan College [J]. Journal of Hainan radio and TV University, 2015, 04, pp.107-111+145.

[4]. Duan Shengfeng, Peng Lifang. "The path of cultivating internationalized talents under the background of The Belt and Road" [J]. Journal of Changsha University of Science and Technology (SOCIAL SCIENCE EDITION), 2016, 01, pp.103-107.

[5]. Luo Wei. Based on the "The Belt and Road" strategy and the regional rail transportation industry demand for internationalized talents training analysis [J]. Western quality education, 2016, 06, pp.22.

[6]. Liu Yanhong. International exchange and cooperation of college under the background of The Belt and Road [J]. Heilongjiang higher education research, 2016, 03, pp.10-14.

[7]. Chang Ying, Li Xiaodong, Zhao Jian, Han Xiaoqiang, Yu Shuzhou, Wei Zhiyong, Hu Ping. Innovation and practice of international personnel training mode for vehicle engineering specialty [J]. Laboratory science, 2014,01, pp.202-204+208.

[8]. Qi Min. International teaching of materials course for equipment manufacturing Specialty--Thinking and Practice [J]. Education and Teaching Forum, 2014, 29, pp.216-217.

[9]. Wu Yumeng. Based on the "The Belt and Road" national strategy for construction project management of international personnel training research $[\mathrm{J}]$. Education and Teaching Forum, 2016, 27, pp.81-82.

[10]. Liu Fei, Ji Peng, Liu Chuanzhi. Research on the bilingual teaching of automobile structure based on the professional internationalized talents training [J]. Journal of Hebei University of Engineering (SOCIAL SCIENCE EDITION), 2016,02, pp.103-104+110

[11]. Jones Glen A., Oleksiyenko Anatoly. The Internationalization of Canadian University Research. A Global Higher Education Matrix, analysis of Multi-Level Governance. Higher Education[J]. The International Journal of Higher Education and Educational Planning, Vo1.61, No.1, January 2011, pp.41-57. 